\title{
ECOLOGY SAFETY TECHNOLOGIES OF UNCONVENTIONAL OIL RESERVES RECOVERY FOR SUSTAINABLE OIL AND GAS INDUSTRY DEVELOPMENT
}

\author{
Viacheslav Zyrin ${ }^{1}$, Alina Ilinova ${ }^{1}$ \\ 1 Saint-Petersburg Mining University, $21^{\text {st }}$ Vasil'evsky Ostrov, Line 2, Saint-Petersburg, 199106, Russia, e-mail: \\ slava19887@yandex.ru, iljinovaaa@mail.ru
}

Received: 2016.06 .02

Accepted: 2016.08.12

Published: 2016.09.20

\begin{abstract}
The problem of effective technology for heavy oil recovery nowadays has a great importance, because of worsening geological conditions of the developed deposits, decreasing recovery factor, increasing the part of heavy oil. For the future sustainable development of oil producing industry the involved technologies must require energy effectiveness and ecological safety. The paper proves the enhanced oil recovery methods necessity for heavy oil deposits, highlighted thermal technologies as the most effective. But traditional thermal treatment technologies is a source of air pollutant emission, such as $\mathrm{CO}, \mathrm{NO}$ etc. The calculation of emissions for traditional steam generator is provided. Besides, the paper shows the effectiveness of electrical enhanced oil recovery methods. The advantages of associated gas as a fuel for cogeneration plants is shown. The main approaches to implementation of carbon dioxide sequestration technologies in the oil and gas industry of Russia are defined. Conceptual view of CO2-EOR technologies potential within the context of sustainable development of oil and gas industry are presented. On the basis of the conducted research a number of scientific research and practical areas of the CCS technology development are revealed.
\end{abstract}

Keywords: heavy oil, ecology safety, electrical enhanced oil recovery, downhole electroheating generator, carbon dioxide, carbon capture and storage (CCS), oil recovery

\section{INTRODUCTION}

Nowadays, oil producing companies face with reducing of light oil reserves, worsening of developed oilfields geological properties, the heavy and high viscosity oil growing importance. Reserves of high viscosity oil are almost in 7 times larger than the conventional ones. Russia is ranked third for heavy oil resources, after Venezuela and Canada.

The main recovery problem relates to physical properties of heavy oil. For this reason, recovery with traditional technologies (water flooding etc.) has no effect (recovery factor is $8-15 \%$ ) and heavy and high-viscosity oil is classified as unconventional. Therefore, enhanced oil recovery (EOR) technologies is required.

Enhanced oil recovery technologies divides into 4 groups:
1. Thermal treatment methods (steam or hot water injection, electrical heating, in-situ combustion, cyclic steam stimulation, steam assisted gravity drainage etc).

2. Chemical methods (flooding with surface active substances (SAS) solution, polymer and alkaline solutions etc.).

3. Gas injection (hydrocarbon gases and CO gases in pure view or mixed with water flooding, furnace and inactive gases).

4. Microbiological methods (inserting bacterial product into the reservoir or growing it inside) [Antoniadi 2004].

Oil producing companies and scientific organizations has proven that thermal technologies is the most effective for heavy oil deposits, mainly because of it hydrodynamic and thermodynamic impact combination. Heat inside the well affects 
the contained components and change bonds and filtration conditions, what results in viscosity reducing, oil mobility improving. Thermal methods have shown high efficiency for oilfields with complete physical-geological conditions, increasing oil recovery factor in several times [Zyrin et al. 2015].

Heavy oil in Russia is related to alternative hydrocarbon source, because of it higher density and complex component composition. Heavy oil contains naphtenic acids, sulfoacids, light and compound ester, titan, nickel, vanadium. The employed technologies do not involve the extraction of valuable components, while nickel and vanadium from heavy oil superior the same oreextracted metals.

Thus, the actual direction for increasing the economic effectiveness of heavy oil deposits developing is creation of up-to-date recovery technologies, providing energy effectiveness and ecology safety.

\section{TRADITIONAL THERMAL TECHNOLOGIES}

From the energy effective view the steambased technologies are preferable for recovering heavy oil deposits. Traditional steam stimulation technology uses the ground steam generators, working on hydrocarbon fuel burning. Steam, produced on the ground generator, through insulated tubing string is injected into the well for heating. For 1 ton of steam producing $1500 \mathrm{~m}^{3}$ of gas is required. The important question for this technology is heat insulation of tubing string, because stem dryness is the main factor, determining the effectiveness of thermal treatment.

Gas burning leads to nitrous dioxide and carbon oxide air pollution. Nitrous dioxide forms as a result of nitrous oxidation under high temperature and fuel nitrous containing. NOx emission according to Russian standard for gas-based plants is $125 \mathrm{mg} / \mathrm{m}^{3}$.Carbon oxide (CO) is an intermediate combustion product; its existence shows the equipment corrosion risk, ineffective fuel combustion and efficiency factor decreasing [Zagrivniy et al. 2012].

Calculation of pollutant emission for traditional steam generator is shown below.

$$
\begin{gathered}
\text { Mco }=\text { Cco } \cdot m \cdot\left(1-\frac{q_{4}}{100}\right) \cdot 10^{-3}= \\
=0.001 \cdot 10.44 \cdot 10500=109 \text { ton } / \text { year }
\end{gathered}
$$

where: $M_{C O}-$ carbon oxide emission, ton/year.

$q_{4}$ - heat loss because of inefficient com- bustion process, $\%, q_{4}=0$;

$m$ - fuel volume, thousands $\mathrm{m}^{3} /$ year;

$C_{C O}$ - carbon oxide emission after fuel combustion, $\mathrm{kg} / \mathrm{ton}\left(\mathrm{kg} /\right.$ thousands $\left.\mathrm{m}^{3}\right)$ :

$$
\text { Cco }=q_{3} \cdot R \cdot Q^{\mu}=0.5 \cdot 0.5 \cdot 41.75=10.44
$$

where: $q_{3}$ - heat loss because of inefficient chemical combustion process, $q_{3}=0.5 \%$;

$R$ - heat loss part factor takes inefficient chemical combustion process, $R=0,5-$ for natural gas;

$Q_{m}$ - net calorific value, $\mathrm{MJ} / \mathrm{kg}, \mathrm{MJ} / \mathrm{m}^{3}$ $\left(Q_{m}=41.75 \mathrm{MJ} / \mathrm{kg}\right)$.

Calculation of nitrous oxide emission in conversion to nitrous dioxide:

$$
\begin{gathered}
M_{\mathrm{NO} 2}=m \cdot Q^{n} \cdot K_{\mathrm{NO} 2}(1-\beta) \cdot 10^{-3}= \\
=0.001 \cdot 10500 \cdot 41.75 \cdot 0.085=37 \text { ton } / \text { year }
\end{gathered}
$$

where: $K_{\mathrm{NO} 2}-$ nitrous oxide producing from $1 \mathrm{GJ}$ of heat $(\mathrm{kg} / \mathrm{GJ})$;

$\beta$ - nitrous oxide emission factor after some technical improvements.

Consequently, for one steam generator the specific pollutant emissions for $1 \mathrm{~m}^{3}$ of fuel are: $10.4 \mathrm{~kg} / \mathrm{m}^{3}$ for carbon oxide, $3.52 \mathrm{~kg} / \mathrm{m}^{3}$ for nitrous oxide.

Russia's Energy strategy requires increasing the production level of unconventional oil and the level of steam injection. Utilization of traditional technologies on the basis of fuel combustion will provide air pollution and a decrease of energy effectiveness in oil production.

\section{ELECTRICAL ENHANCED OIL RECOVERY (EEOR)}

From the ecological point of view, the EEOR is a cleaner technology, moreover, for some deposits it is more effective, because of direct contact with formation [Rehman et al. 2012].

Up-to-date tested and researched EEOR include low frequency heating, using heating cable, inductive heating, electromagnetic treatment. For providing direct wellbore the downhole electrical heating devices are used.

The low-frequency heating method requires two wells, anode and cathode, and electric current flows through formation, heat dissipates, raising the adjoined layers temperature. The heating-cable based technologies are important part of these methods. 
The inductive heating technology include inductively heating element, through generated eddy and displacement currents flows and raise the formation temperature. The main advantage of this method is high energy efficiency [Rehman et al. 2012].

Electromagnetic treatment (ET) include downhole heat source producing inside the formation as a result of high-frequency electromagnetic field action. Heating front depends on voltage, electromagnetic field frequency, formation of electrical properties. ET leads to oil emulsion breakdown, paraffin crystallization temperature lowering, pressure increasing because of power electromagnetic field impact.

The aforementioned technologies are tested and operate in several oilfields, but according to the modern tendency of providing heating process inside the well, the creation of effective downhole electrical generators providing combination of EOR (heat and chemical, etc.) is an actual problem.

Various downhole heating devices have been designed for steam or other heat-producing agent. It uses mostly electrical energy to ignite the fuel combustion process. Some of it use electrical heating elements for gas (nitrous, steam etc) heating and it future injecting into the formation [Barillas 2008].

Downhole electrosteam generators, created in Mining University (Russia) [Litvinenko et al. 2006, Zagrivniy et al. 2012] provides various steam injection technologies (cyclic steam stimulation, impulse dozen steam stimulation, steam injection), hot water producing, combination of chemical and heating technologies. The DESG (downhole electrosteam generator) consists of metal housing with insulated central input lead. Phase and zero electrodes attached to the central input lead one by one. Zero electrodes contact with housing. Water (or other heating agent) is injected from the surface through tubing string into the housing. Current flows from the phase electrodes to the zero through heating agent (salty water, water, chemical diluents) and by means of heat exchange heating and boiling. The main advantage of this device is low capital cost, ecology safety, high steam quality, because of it downhole producing [Zyrin et al 2016].

\section{OILFIELD ENERGY SOURCES}

For electrical enhanced oil recovery methods the most important question is the source of the energy generation.
Heat power station (HPS), without dependence from the fuel, is a source of huge amount of green house gas, which causes global warming. That is why, energy from HPS cannot be classified as clean.

For oilfields, using of associate gas (AG) is of great importance. Average volume of AG in Russia is 50-60 billion cubic meters, average percentage of industrial involvement is $65-70 \%$, and other part is burnt or dissipated into the atmosphere.

One of the effective ways of associated gas implementation is to use it as a fuel for cogeneration plant $(\mathrm{CP})$, which produce heat and electric energy at once.

The main advantage of cogeneration plant over other electrical station is more effective use of the fuel. The efficiency factor of CP is $90-92 \%$, because the plant gathers waste energy in utilization boiler and uses it for energy generation.

Cogeneration expoiltation provides the oilfield independence from power faults or difficulties in power supplying. With the tendency of electrical energy price grows, CP get significant economic effect - reducing heat and energy costs in 2.5-2.8 times.

Statistics show that oil producing companies, involving traditional steam/hot water stimulation is a main atmosphere pollutant.

Analyzing the aforementioned facts, the combination of EOR technologies will provide more effects for the heavy oil deposits, especially thermal treatment using injected gas $\left(\mathrm{CO}_{2}\right.$, nitrous and other) and resultant steam-gas heat agent for oil recovery.

\section{IMPLEMENTATION OF CCS TECHNOLOGIES IN THE CONTEXT OF OIL AND GAS INDUSTRY SUSTAINABLE DEVELOPMENT}

Nowadays promotion of the carbon dioxide capture and sequestration technologies (CCS technologies) by means of capturing and injecting it into the underground reservoirs is a promising method of reducing carbon dioxide $\left(\mathrm{CO}_{2}\right)$ concentration. By the estimates of the International Energy Agency (IEA), contribution of Carbon Capture and Sequestration (CCS) technologies to the worldwide emission reduction may reach 1.5 billion tons of CO2 a year by 2050 [Energy technology prospects. International Energy Agency 2011, WWF - The Energy Report 2011]. 
CCS technologies in general include the following technological processes: capturing, transportation and geological storage.

In particular, geological storage means the possibility of injecting carbon dioxide into the saline formations (water-bearing strata), oil and gas fields, and coalbeds. When injecting carbon dioxide into the saline formations or oil and gas fields, it is necessary to consider mining and geological properties of the rock. The reservoirs should have high porosity to accumulate huge amounts of $\mathrm{CO}_{2}$. The rocks inside are usually impervious, so that carbon dioxide can penetrate into the underground reservoirs. Along with that, the storage reservoirs should be covered with impervious overlying rocks in order to prevent surface leakages. The coalbed storage might be implemented at shallow depths and this method is based on carbon dioxide adsorption by coal. The technical practicability of such a technology depends to a great extent on the coalbed permeability [Cherepovitsyn et al. 2016].

The carbon dioxide storage in oil and gas fields that are at the final production stage might be used to enhance oil recovery $\left(\mathrm{EOR}-\mathrm{CO}_{2}\right)$ and production by means of oil extraction and decreasing oil viscosity.

Enhancing the oil recovery by the EOR- $\mathrm{CO}_{2}$ method may be characterized by the benefit by usage of anthropogenic carbon dioxide, captured at power plants and industrial enterprises. Large volumes of potential carbon dioxide storage in the oil reservoirs (about 340 billion barrels of technically recoverable oil resources) underline the interest in the EOR- $\mathrm{CO}_{2}$ technologies [Beecy et al. 2004].

Experts estimate stimulating oil production by gas, which includes injection of $\mathrm{CO}_{2}$, associated petroleum gas (APG), petroleum gas and flue gas, to be one of the most effective and rational technological processes from the point of view of energy-, resource-saving and EOR.

The conceptual view of oil and gas industry (OGI) sustainable development under the strategic vision of potential vast usage of the CCS technologies is presented in Figure 1 [Cherepovitsyn et al. 2016, Cherepovitsyn et al. 2011].

The main problem of the EOR- $\mathrm{CO}_{2}$ technologies usage is high price of anthropogenic $\mathrm{CO} 2$.

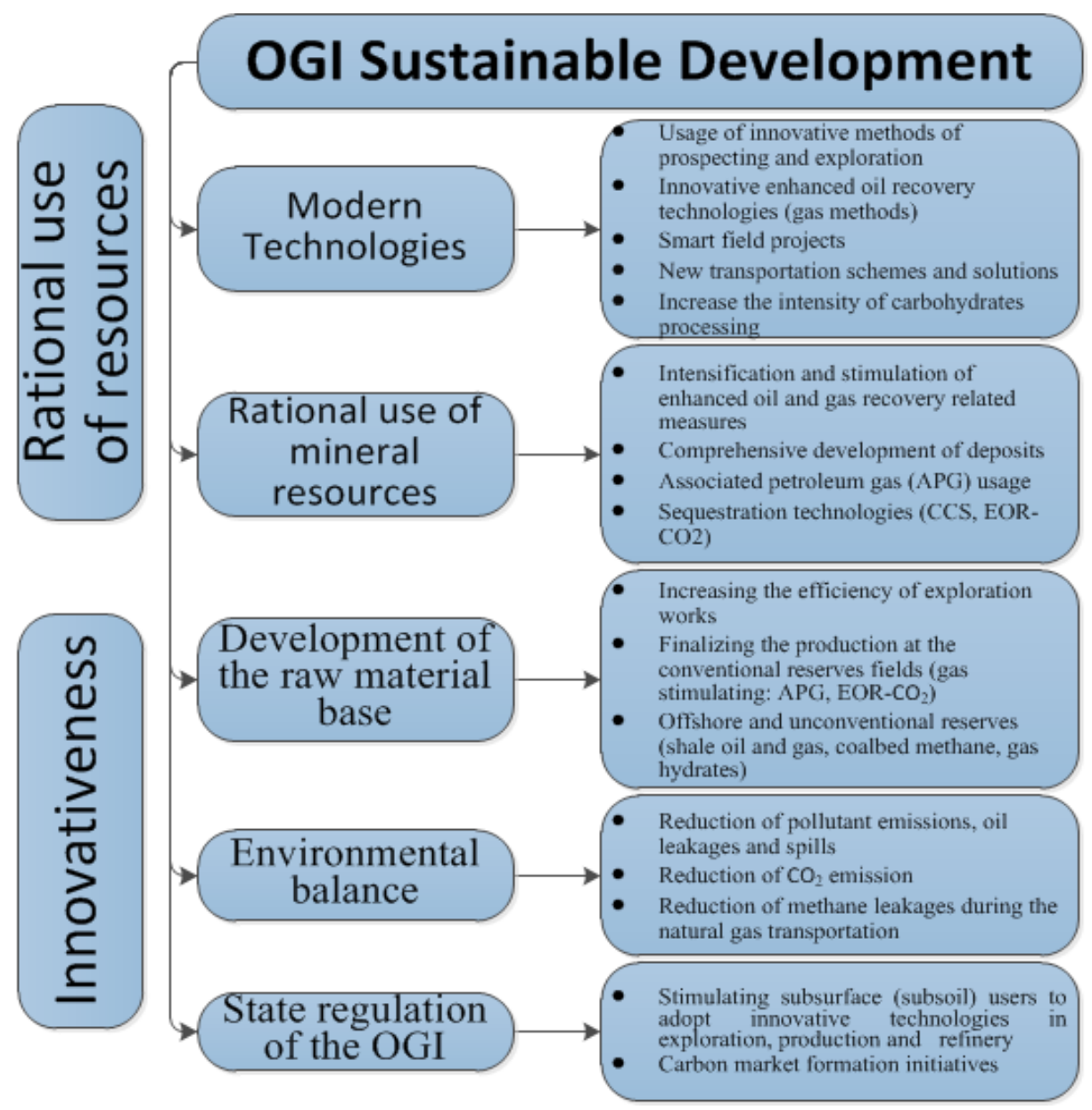

Figure 1. Conceptual view of EOR-CO $\mathrm{CO}_{2}$ technologies opportunities in the context of OGI sustainable development 
Three main processes (stages) - capturing, transportation and geological storage - differ from each other considerably in terms of technical and technological practicability and have different experience of practical application. The costs of the CCS technology implementation depend on particular CCS project, technological and technical features of capturing on power plants and industrial enterprises, mining and geological conditions of fields, distance of transportation etc. The efficiency of the EOR- $\mathrm{CO}_{2}$ technologies usage also depends on the price of carbon dioxide on the carbon market.

The $\mathrm{CO}_{2}$ sequestration costs will also differ at different stages of the technologies development and promotion. Thus, at the initial demonstration stage the cost of such projects remains rather high, especially at the stage of $\mathrm{CO}_{2}$ capturing. In the future, when CCS projects enter the early commercial stage, because of the economies of scale and trainings, the costs of adoption will decrease by approximately $35 \%$. Later, by reaching of the commercial maturity stage the costs of CCS technologies implementation may decrease by extra 10-12\% [Cherepovitsyn et al. 2016].

According to different expert's opinion, the approximate cost of the CCS technologies varies from 1440 to 2136 rubles per ton of carbon dioxide. The cost of capturing is about 1087-1392 rubles per ton of carbon dioxide, the transportation cost is about 179-266 rubles per ton, and the storage cost in oil and gas reservoirs is about 174478 rubles per ton of carbon dioxide [Naucler et al. 2008, Toth et al. 2011].

Injection of carbon dioxide into oil reservoirs is a complicated process. The accurate forecast of the EOR- $\mathrm{CO}_{2}$ technology potential for Russian deposits may be determined by geological and economic modeling and detailed research of the potential reservoir capacity. The economic analysis of the EOR- $\mathrm{CO}_{2}$ schemes is a research, carrying out of which entails additional difficulties related to the necessity of improvement of technical and technological approaches, including the selection and usage of oil production equipment, taking specific capital and operating costs into account, evaluation of geological and investment risks. Furthermore, long-term storage of $\mathrm{CO}_{2}$ in the geological reservoirs implies forming the mechanisms of monitoring of the underground environment and evaluating the risks of potential release of $\mathrm{CO}_{2}$ to the surface. It is necessary to understand who will be monitoring and control- ling the $\mathrm{CO}_{2}$ diffusion process in the underground formations over time [Cherepovitsyn et al. 2016].

The majority of Russian oil and gas fields (Western Siberia) are located in the areas that are remoted from the main industrial $\mathrm{CO}_{2}$ emission sources. The old oil and gas production areas, such as Tatarstan and Bashkiria, the Northwestern region (including Kaliningrad oblast) are the most suitable for the EOR- $\mathrm{CO}_{2}$ methods usage. It is important to evaluate the geological and technical potential of the EOR- $\mathrm{CO}_{2}$ technology, the $\mathrm{CO}_{2}$ storage for the old oil production areas in first place [Ilinova et al. 2016].

\section{CONCLUSIONS}

The EEOR methods are more effective for heavy oil deposits because of direct contact with formation, heat producing inside the well and ecologic safety. Ecological safety provides with using electroheating devices, for instance downhole electrosteam generator, which do not use hydrocarbons fuel for energy generation. However, during ecological safety estimation it is important to take into account the source of electrical energy for EEOR. The associated gas usage is another problem which can be solved by using AG as a fuel for cogeneration plants, producing heat and energy at once with efficiency factor almost $90-92 \%$ or local power station. The produced energy can be consumed by electrical heating devices for formation treatment. Combination of these technologies has a great potential to provide sustainable and effective development of producing company.

An additional point is that the CCS technology is one of the methods of enhancing oil recovery $\left(\right.$ EOR- $\left.-\mathrm{CO}_{2}\right)$ and at the same time a promising mechanism of reducing $\mathrm{CO}_{2}$ concentration. EOR$\mathrm{CO}_{2}$ method may be characterized by the benefit by the usage of anthropogenic $\mathrm{CO}_{2}$, captured at power plants and industrial enterprises. The main problem of the EOR- $\mathrm{CO}_{2}$ technologies usage is the high price of anthropogenic $\mathrm{CO}_{2}$. In that context, formation of conceptual framework of the national $\mathrm{CO}_{2}$ market is a requirement for EOR-CO method usage. Modeling of marginal operating and capital costs of the CCS technology adoption, depending on the prognoses of $\mathrm{CO}_{2}$ market development and technical advancement is necessary condition for CCS projects implementation. Technique of geological, environmental and investment risks evaluation of the CCS projects can also be developed. 


\section{Acknowledgements}

The paper is based on research carried out with the financial support of the grant of the Russian Science Foundation (Project No. 14-3800009, The program-targeted management of the Russian Arctic zone development). Peter the Great St. Petersburg Polytechnic University.

\section{REFERENCES}

1. Antoniadi D. 2004. Nastolnaya kniga po termicheskim metodam dobychi nefti. Krasnodar, Sovietskaya Kuban', 464 p.

2. Barillas J., Dutra T., Mata W. 2008. Improve oil recovery process for heavy oil: a review. Brazilian Journal of Petroleum and Gas, 2(1), 45-54.

3. Beecy D., Kuuskraa V. 2004. Basin strategies for linking $\mathrm{CO}_{2}$ enhanced oil recovery and storage of $\mathrm{CO}_{2}$ emissions. 7th International Conference on Greenhouse Gas Control Technologies, Vancouver, Canada.

4. Cherepovitsyn A., Ilinova A. 2016. Ecological, economic and social issues of implementing carbon dioxide sequestration technologies in the oil and gas industry in Russia. Journal of Ecological Engineering, 17(2), 19-23.

5. Cherepovitsyn A., Ilinsky A. 2011. Geological Disposal of Carbon Dioxide and Radioactive Waste: A Comparative Assessment. Comparison of the Geological Disposal of Carbon Dioxide and Radioactive Waste in European Russia. International Atomic Energy Agency; Springer Dordrecht London Heidelberg New York, 513 p.
6. Energy technology prospects. Strategies and scenarios to 2050. International Energy Agency, 2011. URL: http://www.iea.org

7. Ilinova A., Dmitrieva D. 2016. Technology commercialization: experience of the U.S. and possibilities for oil and gas industry in Russia. International Journal of Applied Engineering Research, 11(7), 4990-4994.

8. Litvinenko V., Kozyaruk A., Soloviev G., Zagrivniy E. 2006. Device for wellbore heat treatment, RU patent 2282018, September 15.

9. Naucler T., Campbell W., Ruijs J. 2008. Carbon Capture \& Storage: Assessing the Economics. Report of McKinsey \& Company. 53 p. URL: http:// assets.wwf.ch/downloads/mckinsey2008.pdf

10. Rehman M., Meribout M. 2012. Conventional versus electrical enhanced oil recovery: a review. Journal Petroleum Exploitation Production Technology, 2, 157-167.

11. Toth F., Miketa A. 2011. Costs of the Geological Disposal of Carbon Dioxide and Radioactive Waste. Springer, 215-262.

12. WWF - The Energy Repor 2011. 100\% Renewable Energy by 2050. WWF/Ecofys/OMA, Gland, Switzerland, 256 p. URL: http://www.wwf.or.jp/ activities/lib/pdf_climate/green-energy/WWF_EnergyVisionReport.pdf

13. Zagrivniy E., Malarev V., Lakota O., Zyrin V. 2012. Downhole electrosteam generator-separator, RU patent 2451158. May 20.

14. Zyrin V., Vasilev B. 2015. Designing the electrothermal complex control system for enhanced oil recovery. International Journal of Applied Engineering Research, 10(24), 44183-44188. 